Int.J. Hum. Soc. Dev. Res.

ISSN (P):2521-1439; ISSN (E):2523-4331

Volume 4, Number 1, 2020. 83-95

DOI: $10.30546 / 2523-4331.2020 .4 .1 .83$

\title{
OF MICE AND MEN: NEW PERSPECTIVES IN THE LIFE OF AMERICAN SOCIETY VIA READING STEINBECK'S NOVELLA
}

\author{
Alaa L. ALNAJM \\ University of Kufa, Iraq
}

(c) The Author(s) 2020

\section{ABSTRACT}

This paper investigates new perspectives in the novel Of Mice and Men by the American writer John Steinbeck. However it studies the most important issues exposed by Steinbeck in American literature and society; these issues became as their existence in different aspects, more specifically the social relationships and enhancing the economic systems. The paper also discusses different issues concerning the life of American people in the era of Great Depression; with this kind of story American people interact with the events displayed by the writer. Therefore, this story reflects their struggle and goals towards fulfilling better lives. It also studies the sense of friendship in American society in particular and society in general. Actually the soft relationship between George and Lennie depicts the hope and love and how to overcome any obstacles which sometimes we meet in our lives. The paper also explains briefly the role of women played in the American society in the thirties of the last century. Moreover, Steinbeck actually promotes women in society throughout the character Curley's Wife and how she challenged all the difficulties she faced not just to be a successful factor in society but also she proved that without woman the movement of our daily life will completely stop.

\section{C2020.A11 rights reserved}

\section{ARTICLE HISTORY}

Received: $25 / 12 / 2019$

Accepted: 13/04/2020

Published online: 27/04/2020

\section{KEYWORDS}

Of Mice and Men, novel, friendship, American dream, Great Depression 


\section{Introduction}

The 20th century especially in 1920, USA witnessed a great development in agriculture and technology; for example the Ford Company gave high salary for its employees to produce lots of automobiles. Electrical power was widespread to extend all over the American states; in addition to people started to spend their leisure time listening to radio broadcasts. Thus all these conditions developed the social state of Americans.

But at the beginning of 1930, American people met many problems and crises; however the most important of them were the Wall Street Crash. Therefore, this created what it was known the Great Depression. American government was unable to solve these problems and people started to lost their trust in government.

The economic crisis was uncontrollable; hundreds thousands of employees lost their jobs. Actually this had created the chaos inside the American society. Moreover, the majority of citizens decided to travel and migrate around United State of America to increase their lives and get better circumstances for their families.

Of Mice And Men is a novella written by the American writer John Steinbeck who successfully depicts a full idea and picture concerning the situation of American society during the Great Depression and he also mirrors what people did to rescue their lives from the crisis and collapse they faced.

John Steinbeck is regarded as one of the most significant writers in American literature. He is from California, Salinas. However, his successful works contribute to English literature. Therefore his famous works are reproduced into films; they reflect the American society during the Great Depression. Nobel and Pulitzer Prizes have made him one of the only writers who depicted the shiny pictures of American society particularly the lives of lower social class.

However, Steinbeck shows his unique literary devices and techniques in writing literature particularly novels; therefore, some critics see him as a inventive creator in American literature. Alabama is one of the best researchers at University of Alabama writes the following: «To support himself during his time at Stanford, he worked as a farm laborer, or at the sugar plant, or as a fruit 
picker. These experiences put him in contact with drifters, migrant workers, and other dispossessed individuals, providing him many of the character resources he would later draw on. Even then, he knew his real aspiration was to be a writer, and so he relished his off-again, on again approach to the university, negotiating his genuine interest in sea life and ecology with a more bohemian approach to living. He stopped attending classes by 1926, and never earned a degree" (Alabama, 2011).

Of Mice And Men is that novel draws the struggle of hard life of Americans during the crash of Wall Street; however, it is a story of migration,race, depression and hardship. Thus this novel is an ideological one that emphasizes on the economic crisis of American life when they met the collapse of economic issues at the beginning of 1929 .

Lennie and George are the major characters in Of Mice and Men, however, they start their journey to get new life in different places in the USA. Moreover, Steinbeck mirrors the life of American society during the Great Depression via these two characters. However, their aim is to achieve what it is known the American Dream. They want to get better life through migration. Therefore, Steinbeck depicts the picture of the American Dream throughout the life of George and Lennie. However, we sometimes see that the dream of George and Lennie reflects the personal life and experience of the writer himself, for example when Lennie and George migrate to California, Salinas to begin new life and build their dream, this of course what Steinbeck decided to do. However, Of Mice and Men represent race, depression, economic crisis and migration throughout the role of each character particularly Lennie and George.

A smart character who simplifies and softens topics is represented by George; while Lennie is that character who reflects feelings and pure thoughts throughout his strong role in the story. However, Steinbeck here shows the sense of friendship via the closed relationship between George and Lennie; therefore, their relationship has continued to extremely extend in order to create their own dream of being able getting a farm full of soft animals such as rabbits.

\section{Of Mice and Men}

Of Mice and Men is one of the most discussed novels in American literature. However; the novel has become a steady part of the curriculum in the United States and Britain. Therefore, students considered the story as one of 
their academic experiences and cultures; they also interact with the events as they live theme. Of Mice and Men is often one of the first Steinbeck stories that readers encounter. If we look at to the style of the novel we find its sentences are crisp, the language simple, and the images are clear. The central idea explored by Steinbeck is the friendly and intimate relationship between the major characters George and Lennie. Moreover, the writer definitely attracts the sympathy of reader towards his characters and their role. Thus the story goes around building relationship of care and concern.

John Steinbeck in his novella Of Mice and Me studies the idea of the 'American Dream'. However; many of the central characters search for a better life. The traveling workers wish to overcome the background of the Great Depression, therefore, they think to begin new lives away from the mundane, unstable and pointless lives. The migrants think that Dreams would provide them with a sense of hope, purpose and belonging. Thus these dreams are pivotal to these characters lives. Some of the characters like George and Lennie want dream as a media to integrate many of the isolated characters in the story to carry out their common goals. The dream of Curley's wife functions as a helpfully mechanism to take her out of her miserable reality. Throughout the novel, Steinbeck portends the problems that may be happen and having dreams may not be sufficient.

Of Mice and Men's title came from the poem of the 18th century Scottish poet Robbie Burns, which was written in an old Scottish dialect? It was about a mouse built a winter nest in a wheat field, but it was been destroyed by a ploughman. The mouse dreamed of a safe, warm winter and is now faced with the harsh reality of cold, loneliness and possible death. However; Steinbeck exposes the life of both George and Lennie and how they wish to have their own farm, this resembles the story of Robbie Burns' poem. The two main themes in Of Mice and Men - foreshadowed by the reference to Burns' mouse - are loneliness and dreams. Therefore, Steinbeck makes his reader feels sympathy towards the case of George and Lennie.

Steinbeck in Of Mice and Men explored the world of migration, opportunity of having good chance to gain very big farm filled with rabbits, pigs, and flowers as what George and Lennie wished. However; the idea of the story started as a play for young people, and Steinbeck called Something that Happened".Moreover,the writer planned to evolve into the story of two farm workers who appear at a ranch after running away from another job. However, 
they dreamed of one day having a farm of their own. George always wanted to protect and save the life of Lennie, a mentally limited individual of great strength who was alone. Lennie loved small creatures like rabbits and mice and a tendency toward violence. They came into contact with Curley, the ranch owner's son, and his wife that leading towards the tragic story. Lennie, who liked things that feel soft, unintentionally killed a mouse and then a puppy. When Curley's wife suggested that he touched her soft hair she also was killed. Curley vowed revenge and decided a posse to hang Lennie. George stole a gun from a farmhand and used it to kill Lennie before the mob could get to him. They spent a little bit time concerning their dream to get a farm in the moments before George pulled the trigger, ending the dream. When it was over, Slim took George up the trail for a drink. A compassionate character, Slim, showed care in a world that, for George.(Bloom:2006,15).

Although, Of Mice and Men is a story that conveys a deeply moral sensibility. However, the noted child psychologist Robert Coles, realizes the moral quality as "the central issue of our existence, the factor that defines the quality of our lives as human beings." Coles also believes that literature can be a source of inspiration, moreover; literature teachers can also feel such of experiences that lead to this inspiration. "Literature can be a moral catalyst," he observes, "because great writers explore a serious question; why do people do what they do?". Therefore, Steinbeck finds this question in the story of George and Lennie. Their commitment to each other and to a dream persists despite their flaws and limitations. However; Steinbeck's concern with human connection and a quality of care is revealed by his story.

Coles adds :"Morality defines not only how we get along with the world and one another and the rules of life: it characterizes our very nature." However, he writes that morality has to do with human connection. "It has to do with the kind of connection that responds to others, and in turn earns the caring response of others." Steinbeck hopes that something can be learned that will increase the kind of connection that responds to others" in a fashion of respect. In his work and in that of Coles is a belief that literature can contribute to this connection. In The Call of Stories: Teaching and the Moral Imagination, Coles recalls the comments of a student who told him that the experiences of some characters in literature helped him to make choices: "they really speak to me," he said, "there's a lot of me in them, or vica-versa." 
Generally, John Steinbeck's Of Mice and Men, yet is criticised by many feminist readers. However, there are some reasons behind this criticism. One of the most discussed is that the woman character in the novel has no name. Therefore, this represents the negative aspect of the novel; otherwise, either the writer wants to ignore the role of women in his writing or has a hidden purpose.

However, Curley's wife represents the woman and her problems in American society in 1930. Typically, she reflects what the women feel and think in that time. Therefore, the jealousy of Curley towards his wife is seen very clear, for example he always tries to keep his wife at home; on the other hand, Curley's Wife wants to make relationship with many people to express her feeling and attitude. She explains his mood as we see in the her speech: "Why can't I talk to you? I never get to talk to nobody. I get awful lonely. (Steinbeck:1937,86). Thus, she tells Lennie that her relationship with her husband was very distant, moreover,Curley's attitude was cold.

Lennie's mental limitations make him separate from his society. However; he is refused by all people in his life except George. The majority of society feel fear when they see his physical strength and unable to control it. Steinbeck explains in his words how sometimes some people have physical strength but they are weak mentally as the case of Lennie. Moreover, Steinbeck portrays the handicap of Lennie to attract the sympathy for him. Therefore, when reader interacts with the whole of events in Of Mice and Men he/she understands completely the misery and oppression of Americans in the thirties of the last century, this is exactly what Steinbeck wants to convey throughout his writings.

Additionally, Curley's wife dreams to be an actress, but unfortunately she couldn't achieve it. However, She also blames her mother because she wants to run away from her mother and problems. Indeed, she thinks that her marriage with Curley would be modified her problems. Unfortunately, she looks bird who lives in the cage. Her situation can help us to make a connection with the women's mood in the society during the 1930s.

\section{Of Mice and Men represents the American Society and their} Dream

John Steinbeck wrote Of Mice and Men in 1937. However, in this novel, the Great Depression times, American Dream and the social problems of 
the American Society were depicted. Therefore, Steinbeck showed the reflections of the social problems deeply via Of Mice and Men to demonstrate the relationships between the novel and 1930s. Therefore, some specific examples are given to make it understandable.Thus, we must know the period and some of the important events of the period. The writers of that period influenced of what happened inside their society. In McIlvaine's research, gives us an idea of the influences on the American writers: "The Great Depression gave rise to a new cohort of important American writers. John Dos Passos, Zora Neale Hurston, William Faulkner, John Steinbeck, Thomas Wolfe, and Richard Wright all did their most important writing in the thirties. Oftentimes their work spoke directly to the social and political conflicts that had been created by the era's economic catastrophe" (Robert S.McElvaine, 2004).

Although, we have seen that the research above shows how writers were been influenced by the Great Depression and the problems of American society. However; writers such as John Dos Passos, Zora Neale Hurston, William Faulkner and John Steinbeck gave some resolutions to the problems pertaining Wall Street Bank Crash and Great Depression.( Boyer:2010,38).Therefore, Steinbeck portrays the American society in 1930 depending on Of Mice and Men; however, he begins his story from Salinas, California. He studies the problem of migration and how migrants encountered the hard circumstances to get job and make their life better. In addition to, Steinbeck also discusses the role of women in American society throughout the character Curley's wife. Throughout the novel Steinbeck conveys his message, for example he explains the American Dream via the conversation of George and Lennie in which they dreamed to have a farm with rabbits, pigs, chickens and cows.

\section{The Great Depression}

The life of the American people had been changed after the World War I; however, the economy began to increase particularly in the second half of the 1920. Therefore, day by day the technology and economic position got better. The invention of electricity, widespread of using radio, and manufacturing of automobiles, were the main goals and necessary needs of any American citizen. In addition to, the company of Ford for making cars paid too much salaries to its employees. Moreover, The banks elaborated everywhere; therefore, Americans saved their money at these banks. (Taylor:2002,40). 
The main events of 1920 are: Prohibition (18th Amendment), Speakeasies, Jazz, The Harlem Renaissance, Electricity, Infrastructure, Transportation, Radio, Women's Suffrage (19th Amendment), Flappers \& Vamps, Scopes Trial, 1925, $\mathrm{Ku}$ Klux Klan, Spectator Sports, Exploring Antarctica, The Stock Market (crash), 1929. However, the Stock Market Crash created a abig disaster in the life of American because people thought that their life will be better completely after the great revolution in technology and economy. Therefore, The Stock Market Crash and The American Dream became the most important events of the 1930s. Indeed, unthinkable thing happened. The "crash" begins on October 24 (Black Thursday). "By October 29, stock prices will plummet and banks will be calling in loans. An estimated $\$ 30$ billion in stock values will "disappear" by mid-November". (Foundation, 1996-2013). Rothbard discusses the spirit of this period :"Unemployment rose over the same period from mere 3.2 percent to 24.9 percent in 1933, and 26.7 percent the following year. At one point, 34 million men, women, and children were without any income at all, and this figure excluded farm families who were also desperately hit". (Rothbard, 2000).

However,the Great Depression is reflected by John Steinbeck's Of Mice and Men. He displays his characters and their migration to California to find a job and make money in the novel. Thus we see the characters like George and Lennie look as they are jobless, without money, agricultural worker. Steinbeck says the following sentences: "Guys like us, that work on ranches, are the loneliest guys in the world. They got no fambly. They don't belong no place. They come to a ranch an' work up a stake and then they go into town and blow their stake, and the first thing you know they're poundin' their tail on some other ranch. They ain't got nothing to look ahead to." (Steinbeck: 1937, 8)

\section{Friendship in Of Mice and Men}

Aristotle is regarded as the greatest philosopher in attempting to discuss and examine the deep meaning of friendship in different ways. However, Steinbeck in Of Mice and Men reflects the real meaning and the moral dimension of friendship throughout the relationship between George and Lennie. Therefore, many critics believe that Of Mice and Men is the finest and masterpiece of Steinbeck's works in which he exposed the thoughts behind being a royal friend towards your friends and society. Thus we may find George struggles to defend and save the life of his friend Lennie. 
Before passing to understand and study the sense of friendship in the novella Of Mice and Men, we have to look at some definitions relating the word friendship. Merriam -Webster Dictionary defines the word friendship as:" 1.state of being friends 2 . The quality or state of being friends"(web1). On the other hand the Urban Dictionary gives another definition for the word friendship:" Friendship is when you love someone with every ounce of your being and genuinely want them to be happy even if it means sacrificing something yourself to make them happy. A true friend is someone you can talk to about your feelings, someone you can tell things you could never tell your family or even your partner. They are someone who you don't have to talk to but someone you want to talk to; someone you will go out of your way to be with. Friendship is when you love someone so much you want to hold them and never let go, someone you want to rest your head on and cry, and you would let them cry on you too. Its someone you can talk to about things you disagree on and end up being closer for that disagreement. Its when you think about someone and how close you are to them and how much you love them and you smile and are happy all over"(web2).

However, if we see the relationship between George and Lennie we find it is a mix of hard and happy times they shared; moreover their relationship is so complex in which it sometimes depends on the experiences and knowledge they spent together. Although, explaining friendship is somewhat difficult in which it requires some social points that surrounding friends. For example, if we look at the friendship of George and Lennie we could find and feel the complexity they have for several years. Therefore, Steinbeck offered in powerful insights and affections this relationship; however, he expressed the American Dream of each individual via the relationship of George and Lennie.(Burkhead:2002,23).

Genuinely the other important thing here we should study is the shared affection in friendship. However, if we read Of Mice and Men, we could expect that the affection between George and Lennie is not short. For instance the last night they spent time together and George told Lennie that he could live without his help and support, George replies "Yea? How'd you eat? You ain't got sense enough to find nothing to eat." Later George relies on how mean his comment was and this is where the affection between George and Lennie is seen. George says "I been mean, ain't I?" "NO-look! I was jus' foolin, Lennie. Cause I want you to stay with me. Actually, Steinbeck precisely combined between two meanings in which he related between criminology and sociology throughout the situation of shooting Lennie. However, George never wanted to kill his friend 
Lennie; what he intended to do was he wanted to free Lennie from the hardest reality of life, he also believed that if he ends the life of Lennie, they would be more peaceful.

Fraternity and the idealized male friendship is one of the main themes explored by Steinbeck. However, this relationship reflects the life of the migrant workers during the Great Depression particularly in 1930. George and Lennie's friendship has very deep impact in the life of other characters in the story. Moreover, their relationship expresses the profound attitude towards responsibility to help and support people especially those who suffer from weak mental problems as the case of Lennie. Thus it should be noted that the majority of male characters always try to live as they are one person to showing the sense of friendship and brotherhood.

Friendship is one most essential for the fulfilment of George's and Lennie's dream. However; their friendship must be distinctive to make the dream remarkable. In fact there are ordinary friendships in Of Mice and Men such as Slim and Carlson, Candy and Crooks. But bond between George and Lennie is quite different in which it goes back many years. Therefore Lennie suffers from mental limitations, and he needs George to guide and protect him. Lennie sometimes threatens to live in a cave in the hills, this shows he always needs George to cover his necessary needs. Regularly George, complains about having to take care of Lennie. However he always forgives Lennie, thus this tolerance gives him a sense of superiority. At the same time, things couldn't be achieved by Lennie make George feels a genuine affection. Most importantly, we could understand that this friendship sustain the dream. However; friendship leads to hope then to dream. Unfortunately, the dream and the friendship are demolished by the reality of their brutal life. Although George is condemned to be alone and a survivor at the end of the story.

Ultimately, however, we live in world filled with harshness and crisis but we still hope to have a good relationship with each other in order to build a realistic society. However Lennie and George, who always show how to achieve their dreams of being able to gain farm and make their life bette; but their life were forced to end tragically. With this, a rare friendship vanishes, but the rest of the world-represented by Curley and Carlson, who watch George stumble away with grief from his friend's dead body_fails to acknowledge or appreciate it. 


\section{Main objectives and research questions}

The main objectives of this paper are :

1.To generate and develop new knowledge of how Dream is expressed, constructed, negotiated in American literature and culturally diverse settings, and to assess the relative roles of American society in this process; and 2.To combine and refine methodological approaches and theoretical perspective.

I aim to accomplish these goals through our focus on the study Of Mice and Men and will investigate in what ways it presents new understandings of dream, friendship and social issues in our society.

In order to achieve its main objectives, this paper aims to answer the following research questions:

- How are group and individual formed and influenced by narrative?

- How does literature particularly novel represent and interpret the impact of the migrant experience in regards to integration and communication.

\section{Conclusion}

Dream is one of the main themes exposed by Steinbeck's Of Mice and Men. However; the author offers a couple of impoverished workers driven by a single dream that looks unattainable. Moreover, Steinbeck continually makes their dream alive to keep this friendship, he also depends on the other characters to attract the attention of reader that George and Lennie's dream might actually succeed to accomplish their goals. Nevertheless, that dream is not completely accomplished. And the other characters like Curley's wife unfortunately did not fulfill their dream and in the same time they were the most devastated.

John Steinbeck's Of Mice and Men reflects clearly what the period of 1930s in America and American Society occurred. However, It is published in 1937. The setting of the novel takes a place in California where Steinbeck was born in. Therefore, Steinbeck had been worked in his early life as an agricultural worker. Thus, this helpfully makes everything very easier to support the work of the writer in doing his work precisely. 
Generally, one of the most significant issues in the life of characters is gaining money and this dehumanizes them. Thus exploitation is actually one of the most important forms of dehumanization since the landowners in one way or another selfishly manipulate the hard conditions of migrant workers. I think that Steinbeck's perspectives resemble partially the doctrine of Karl Marx. However; he is considered as one of the pro-Marxists because of his thoughts to capitalism throughout his exposing the characters in his story. However, perhaps capitalist system in some circumstances could give opportunities to have property and wealth for everybody, but the greedy nature of human beings has become a big obstacle on the way of this system.

Friendship in Of Mice and Men is one of the most significant themes offered by the writer; however this theme positively helps and supplies some kind of hope and love for example George throughout his role doesn't stop helping his friend Lennie. This relationship of course reflects their goals to reach out the dream they always wait for to fulfill it. So we have seen how Steinbeck discusses the sense of friendship in Of Mice and Men to agitate the sympathetic aspect of our life.

\section{Disclosure statement}

No potential conflict of interest was reported by the author.

Contact Information.

Email address: alaal.alnajm@uokufa.edu.iq 


\section{References and notes:}

Alabama, E. D. (2011). Critical Insights John Steinbeck. Pasadena, California Hackensack, New Jersey: salem press.

Armstrong, D. (n.d.). Steinbeck: Social Justice Advocate during the Great Depression.

Bloom, H. (2006). Bloom's Guides: Of Mice and Men. Chelsea House.

Boyer, P. S. (2010). The Enduring Vision A History of The American People, concise sixth edition.

Boyer, P. S. (2010). The Enduring vision The History of American Society.

Burkhead, C. (2002). Student Companion to John Steinbeck. London: Greenwood Press.

Burkhead, C. (Copyright (C) 2002). Student Companion to John STEINBECK. Greenwood Press.

Foundation, W. E. (1996-2013). Timeline: Timeline of the Great Depression. Retrieved from American Experiences: http://www.pbs.org/wgbh/americanexperience/features/timeline/railstimeline/

$\begin{array}{llll}\text { John } & \text { Steinbeck } & \text { Biography.(n.d.). } & \text { Retrieved }\end{array}$ http://classiclit.about.com/od/steinbeckjohn/p/John-Steinbeck.htm.

JOHN STEINBECK: GREAT DEPRESSION. (n.d.). Retrieved from http://www.shmoop.com/john-steinbeck/great-depression.html.

Rothbard, M. N. (2000). America's Great Depression. by The Ludwig von Mises Institute.

Steinbeck, J. (1937). Of Mice and Men.

Taylor, D. E. (2002). Race, Class, Gender, and American Environmentalism. University, T. C. (n.d.). The Great Depression: California in the Thirties.

www. Merriam-Webster.com

www. urbandictionary.com 